\title{
Eksplorasi motivasi relawan: Sebuah perspektif indigenous psychology
}

\author{
Hanif Akhtar*, Ratih Eka Pertiwi, \& Muhammad Fath Mashuri \\ Fakultas Psikologi, Universitas Muhammadiyah Malang, Malang, Jawa Timur
}

\begin{abstract}
Abstrak
Penelitian ini bertujuan untuk memetakan motivasi individu dalam melakukan kegiatan kerelawanan menggunakan pendekatan Indigenous Psychology. Responden penelitian terdiri atas 315 orang relawan di Indonesia. Pengambilan data menggunakan open-ended questionnaire. Hasil kategorisasi terhadap jawaban responden menunjukkan terdapat delapan kategori motivasi menjadi relawan, yakni nilai pribadi $(32,2 \%)$, pengembangan diri $(13,6 \%)$, kepedulian lingkungan $(12,6 \%)$, minat kegiatan $(11,6 \%)$, perasaan positif $(9,7 \%)$, protektif $(8,7 \%)$, hubungan sosial $(6,9 \%)$, dan religiositas $(4,7 \%)$. Analisis data menemukan bahwa ada perbedaan yang signifikan intensi untuk menjadi relawan kembali berdasarkan jenis motivasinya. Implikasi hasil penelitian untuk pengelolaan relawan di masa depan akan dibahas dalam artikel ini.
\end{abstract}

Kata kunci: Motivasi, Relawan, Indigenous Psychology

\begin{abstract}
This study aims to explore individual motivation in volunteerism using the Indigenous Psychology approach. The respondents consisted of 315 volunteers in Indonesia. We collected the data by using the open-ended questionnaire. The categorization results of respondents' answers indicate that there were eight categories of motivation to become volunteers, namely personal values $(32.2 \%)$, self-development (13.6\%), community concern $(12.6 \%)$, interest in the activities (11.6\%), positive feelings (9.7\%), protective (8.7\%), social relations (6.9\%), and religiosity (4.7\%). Our analysis on the intention to volunteer based on motivation category found that there was a significant difference in intention to volunteer based on motivation. The implications of the results of research for future volunteer management will be discussed in this article.
\end{abstract}

Keywords: Motivation, Volunteer, Indigenous Psychology

\section{Pendahuluan}

Berbagai permasalahan sosial yang terjadi seringkali tidak bisa ditangani sendiri oleh pemerintah. Misalnya, pada kondisi terjadinya ketimpangan kualitas pendidikan, bencana, konservasi alam, serta aktivitas politik di berbagai daerah di Indonesia. Inisiatif muncul dari berbagai kalangan untuk membantu menangani masalah yang terjadi melalui kegiatan kerelawanan. Berdasarkan survei yang dilakukan oleh Gallup (2018), Indonesia menempati urutan teratas sebagai negara yang paling dermawan. Hal ini ditunjukkan dengan keterlibatan mayoritas subjek dalam kegiatan kerelawanan, melakukan donasi, dan menolong orang asing yang membutuhkan.

Meski awalnya kerelawanan merupakan aktivitas yang sporadis, komunitas-komunitas

Naskah masuk: 27 Desember 2019

Naskah diterima: 24 Juni 2020 relawan yang lebih terorganisir pun kemudian bermunculan. Berbagai komunitas relawan seperti Palang Merah Indonesia, Indonesia Mengajar, Indonesia Menyala, Aksi Cepat Tanggap, Komunitas Jendela, Pencerah Nusantara, Komunitas Indorelawan, dan sebagainya menjadi lebih populer. Isu sosial yang menjadi perhatian dari tiap komunitas maupun gerakan kerelawanan sangat variatif. Kegiatan kerelawanan dapat dikatakan menjadi bagian dari kehidupan seharihari, tetapi riset terkait topik ini di Indonesia tergolong minim; di antaranya yang telah dilakukan oleh Siswomihardjo (2017) yang mengelaborasi motivasi relawan, secara spesifik di bidang kerelawanan politik di Indonesia.

Perilaku relawan sangat erat kaitannya dengan dengan konsep prososial dalam Psikologi (Slattery, Finnegan, \& Vidgen, 2019). Tindakan prososial menjadi bagian penting yang

*Fakultas Psikologi, Universitas Muhammadiyah Malang Jl. Raya Tlogomas No. 246, Kota Malang, Jawa Timur 65145 E-mail: hanifakhtar@umm.ac.id 
menyertai perilaku membantu dan aktivitas sebagai seorang relawan di berbagai budaya (Aydinli, Bender \& Chasiotis, 2013). Secara konseptual, perilaku prososial merupakan suatu tindakan individu untuk menolong orang lain yang dilakukan tanpa memberi manfaat langsung pada diri penolong. Lebih lanjut, perilaku prososial memiliki kecenderungan untuk tidak menyertakan kepentingan individual, serta dilakukan secara sukarela (Baron \& Brascombe, 2012; Baron \& Byrne, 2004). Jika merujuk pada konteks makro, kerelawanan merupakan salah satu representasi perilaku prososial dalam skala yang lebih besar dan dilakukan dengan perencanaan yang matang (Schroeder \& Graciano, 2018). Aktivitas kerelawanan memang merupakan representasi perilaku prososial, akan tetapi aktivitas ini tidak dapat dipisahkan dari keberagaman motivasi prososial yang menyertainya.

Beberapa studi sebelumnya menjelaskan bahwa motivasi perilaku prososial berada pada dua dimensi, yaitu pleasure dan pressure. Dimensi pleasure terdiri dari motivasi untuk aktualisasi diri, memiliki self-esteem dan self efficacy yang mumpuni, pengaruh kepribadian tertentu (seperti extraversion dan agreeableness), internalisasi nilai-nilai religiositas secara personal sehingga merasa ada kewajiban moral untuk melakukannya, serta perasaan yang berkaitan dengan tercapainya kepuasan hidup. Kondisi ini seringkali disebut sebagai motivasi intrinsik. Sementara pressure merupakan motivasi perilaku prososial dikarenakan adanya dorongan tertentu yang berasal dari luar individu atau motivasi ekstrinsik, seperti pertimbangan mengenai rewards yang didapatkan, dan tekanan dari lingkungan atau relasi sosial (Carlo, dkk, 2005; Gebauer, dkk., 2008; Harrison, 1995; Stavrova \& Siegers, 2014). Riset lain menunjukkan bahwa motivasi intrinsik menjadi faktor penting atas kuat-lemahnya motivasi individu dalam sebuah aktivitas kerelawanan, serta berperan terhadap tingkat produktivitas mereka pada berbagai kegiatan (Grant, 2008).

Walaupun motivasi intrinsik dianggap sebagai motivasi yang penting, riset-riset lainnya menyebutkan bahwa motivasi semacam itu cenderung hanya terjadi pada sebagian kecil relawan saja dalam aktivitas kerelawanan (Smith, 1981). Riset lain bahkan beranggapan bahwa motivasi eksternal bisa jadi memainkan peranan penting. Altruisme bisa menguntungkan diri sendiri baik disadari maupun tidak disadari. Walau ditopengi oleh motif-motif prososial, kegiatan kerelawanan bisa meningkatkan citra diri, memberi keuntungan dari segi status sosial, dan memberikan kebermaknaan bagi diri agar diri merasa berharga (Brunell, Tumblin, \& Buelow, 2014; Konrath, Ho, \& Zarins, 2016).
Pemisahan kedua jenis motivasi ini sangatlah general dan belum menyentuh aspek spesifik dari motivasi dan ragam motivasi itu sendiri secara fenomenologis. Padahal, eksplorasi fenomenologis lewat moda kualitatif dbutuhkan terutama untuk mengeksplorasi konteks-konteks lokal non-Barat yang belum diketahui. Sebelumnya memang sudah ada riset yang menginvestigasi motivasi kerelawanan secara fenomenologis (Yeung, 2004). Dari situ muncul sebuah model teoretis yang disebut model oktagon dari motivasi relawan. Dalam teori ini, motivasi seperti agama dan nilai tradisional dianggap kurang relevan karena respon partisipan mengindikasikan kuatnya modernisme dan sekulerisme. Akan tetapi, pada konteks negara dengan tingkat keyakinan agama seperti Indonesia, asumsi itu menjadi tidak relevan.

Dengan kata lain, konteks lokal dari budaya yang masih jarang diteliti juga perlu diinvestigasi. Salah satunya adalah budaya Indonesia. Apalagi, motivasi-motivasi kerelawanan mungkin sangat ditentukan oleh konstruksi sosial dan struktur sosial yang ada dalam masyarakat. Penelitian dengan pendekatan indigenous psychology menjadi hal yang penting dilakukan karena motivasi relawan sangat erat kaitannya dengan kondisi ekonomi dan sosial budaya masyarakat. Oleh karena itu, strategi untuk pemenuhan motivasi yang dilakukan di kultur barat belum tentu sesuai dengan latar budaya Indonesia. Studi dalam konteks Indonesia akan memberikan informasi yang lebih kaya jika digunakan untuk kepentingan praktis, yaitu guna menentukan strategi pengelolaan relawan pada masyakarat Indonesia.

Peneliti kemudian mengidentifikasi sejumlah motivasi relawan dari lima studi yang berbeda, baik itu secara konteks maupun sampelnya (Allison, Okun, \& Dutridge, 2002; Chacón, dkk., 2010; Clary, dkk., 1998; Omoto \& Snyder, 1995; Schroeder \& Graziano, 2018). Dari kelima studi tersebut, peneliti menemukan ada 13 motivasi yang berbeda, yakni: value (nilai pribadi), enhancement (pengayaan), understanding (pemahaman), protective (protektif), social (sosial), career (karir), community concern (kepedulian sosial), social relation (hubungan sosial), religiosity (religiositas), enjoyment (kesenangan), team building (membangun tim), dan interest in the activity (minat pada kegiatan).

Penelitian terdahulu terkait motivasi relawan dinilai banyak menggunakan instrumen berupa pertanyaan tertutup atau skala yang memungkinkan peneliti dapat memperoleh skor pada masing-masing jenis motivasi. Kelemahan instrumen semacam ini adalah subjek dibatasi pada jenis motivasi yang diukur saja, padahal dalam kenyataannya subjek bisa memiliki moti- 
vasi yang lebih bevariasi (Allison, dkk., 2002). Motivasi merupakan anteseden utama suatu tindakan, sehingga akan lebih substansial jika digali maknanya pada masing-masing individu. Oleh karena itu, studi eksploratif dengan jenis pertanyaan terbuka penting dilakukan untuk memberikan gambaran kontekstual mengenai motivasi relawan di Indonesia.

Penelitian ini bertujuan memetakan motivasi individu dalam melakukan kegiatan kerelawanan berdasarkan latar budaya Indonesia dengan menggunakan pendekatan indigenous Psychology. Penelitian ini juga bertujuan mengeksplorasi motivasi relawan ditinjau dari karakteristiknya (jenis kelamin dan usia) dan hubungannya terhadap intensi untuk menjadi relawan kembali. Hal ini berimplikasi pada manfaat praktis dari penelitian, yakni dapat menjadi dasar rekomendasi bagi organisasi nirlaba untuk melakukan pengelolaan relawan. Pengelolaan relawan yang dimaksud meliputi proses rekrutmen, penentuan target relawan, proses seleksi, pengembangan program, dan pelatihan relawan. Sementara secara teoritis hasil penelitian ini diharapkan memberikan kontribusi bagi pengembangan keilmuan Psikologi dalam memahami motivasi relawan di Indonesia.

Temuan penelitian sebelumnya menemukan bahwa motivasi menjadi relawan ditentukan oleh usia (Dávila \& Díaz-Morales, 2009; Okun \& Schultz, 2003) dan jenis kelamin (Burns, dkk., 2008; Ibrahim \& Brannen, 1997). Misalnya, hasil riset Dávila \& Díaz-Morales (2009) menyatakan bahwa seiring bertambahnya usia, individu akan cenderung meningkat motivasi nilai pribadi dan sosialnya, tetapi motivasi pengembangan diri dan karirnya relatif menurun. Selain itu Burns, dkk. (2008) juga menyatakan bahwa perempuan memiliki motivasi nilai pribadi, pemahaman, dan pengayaan yang lebih tinggi dibanding laki-laki. Temuan-temuan tersebut memiliki nilai implikasi praktis dalam menentukan strategi mengelola relawan, khususnya dalam menentukan target relawan yang hendak direkrut. Namun sayangnya, penelitian serupa dalam konteks masyarakat Indonesia belum pernah dilakukan.

Saat ini, dapat dikatakan bahwa hampir semua lembaga nirlaba memerlukan tenaga relawan untuk menjalankan programnya (Rachmawati \& Abdullah, 2015). Oleh karena itu, diperlukan strategi yang sesuai untuk merekrut, mengembangkan, dan mempertahankan relawan. Peneliti menilai bahwa eksplorasi motivasi relawan secara lebih luas, terkhusus pada konteks keIndonesia-an sangat penting untuk dilakukan karena motif yang muncul pada relawan akan menentukan strategi pengelolaannya. Gagasan yang mendasari strategi ini adalah bahwa kepuasan akan pemenuhan motivasi adalah faktor kunci untuk mempertahankan relawan (Chacón, Pérez, Flores, \& Vecina, 2010).

\section{Metode Penelitian}

\section{Desain}

Penelitian ini merupakan penelitian survei dengan pendekatan Indigenous Psychology. Penelitian dilakukan pada individu yang sedang atau pernah mengikuti aktivitas kerelawanan. Data diambil dengan pertanyaan terbuka dan dianalisis secara bottom-up, yakni dari data menjadi suatu tema atau kategori motivasi berdasarkan konteks budaya Indonesia. Penelitian terbagi menjadi dua tahap, yakni tahap kategorisasi data dan tahap eksplorasi data. Metode analisis yang digunakan pada tahap pertama adalah kualitatif dengan kategorisasi berdasarkan tema yang ada, dilanjutkan dengan analisis tahap kedua secara kuantitatif. Kami tidak mempertentangkan kedua metode pengambilan data karena keduanya dapat digunakan secara eklektik, sesuai dengan asumsi teori kebenaran pragmatisme (Butts, 1966).

\section{Instrumen penelitian}

Penelitian ini menggunakan open-ended questionnaire untuk melihat motivasi relawan yang muncul pada relawan. Secara umum pertanyaan utama untuk mengetahui motivasi relawan, yaitu "Mengapa Anda memutuskan untuk menjadi relawan?". Selain itu ada beberapa pertanyaan lain yang berfungsi untuk memperkaya data, seperti pertanyaan mengenai lama menjadi relawan, bidang kerelawanan, frekuensi menjadi relawan, peran sebagai relawan, dan hal yang didapat setelah menjadi relawan. Sementara untuk mengukur intensi untuk menjadi relawan kembali, peneliti menggunakan singleitem yang berbunyi, "Seberapa kuat anda ingin terlibat lagi sebagai relawan?". Item dijawab dengan skala 1-10, dengan skor 1 berarti sangat tidak ingin dan skor 10 berarti sangat ingin.

\section{Partisipan}

Responden penelitian ini merupakan 315 orang relawan yang berasal dari berbagai daerah di Indonesia. Subjek mengisi kuesioner online yang didistribusikan ke beberapa kelompok atau komunitas relawan. Mayoritas subjek penelitian ini adalah perempuan $(62,9 \%)$ dengan tingkat pendidikan paling banyak adalah S1 (61\%). Rata-rata usia subjek adalah Mean = 26,84 dan SD $=6,12$. Subjek berasal dari berbagai latar belakang pekerjaan, tetapi sebagian besar masih menjadi pelajar/mahasiswa yakni 
sebesar 34,3\%. Subjek dalam penelitian ini merupakan relawan dalam berbagai bidang, dan satu orang relawan memungkinkan menjadi relawan dalam dua bidang atau lebih. Dari data yang terkumpul, sebagian besar subjek menjadi relawan dalam bidang pendidikan $(37,3 \%)$, sementara relawan yang paling sedikit berkecimpung di bidang olah raga $(2,5 \%)$. Data demografi subjek secara lengkap dapat dilihat pada Tabel 1.

Tabel 1.

Data Demografi Subjek Penelitian

\begin{tabular}{llll}
\hline Variabel & & Jumlah & Persentase \\
\hline \multirow{2}{*}{ Jenis kelamin } & Laki-laki & 117 & $37,1 \%$ \\
\multirow{3}{*}{ Usia } & Perempuan & 198 & $62,9 \%$ \\
& $15-24$ tahun & 86 & $27,3 \%$ \\
& $25-34$ tahun & 193 & $61,3 \%$ \\
Pendidikan & 35 tahun ke atas & 36 & $11,4 \%$ \\
& SMA & 25 & $7,9 \%$ \\
& S1 & 192 & $61 \%$ \\
S2 & 93 & $29,5 \%$ \\
S3 & Pelajar/mahasiswa & 5 & $1,6 \%$ \\
& Pegawai swasta & 121 & $38,4 \%$ \\
& PNS & 108 & $34,3 \%$ \\
& Wiraswasta & 33 & $10,5 \%$ \\
Tidak/belum bekerja & 26 & $8,3 \%$ \\
& Kebencanaan & 27 & $8,6 \%$ \\
& Kesehatan & 87 & $16,6 \%$ \\
& Lingkungan hidup & 78 & $14,9 \%$ \\
& Olah raga & 80 & $15,2 \%$ \\
& Pendidikan & 13 & $2,5 \%$ \\
& Politik & 196 & $37,3 \%$ \\
& Seni & 14 & $2,7 \%$ \\
& Sosial & 24 & $4,6 \%$ \\
& & 33 & $6,3 \%$ \\
\hline
\end{tabular}

\section{Prosedur}

Pengambilan data dilakukan secara online menggunakan google form yang tautannya disebarkan melalui aplikasi Whatsapp di beberapa komunitas relawan. Hanya individu yang pernah atau sedang menjadi relawan saja yang datanya dipakai. Seluruh responden diberikan penjelasan mengenai tujuan penelitian dalam pengantar pengisian kuesioner dan mengisi persetujuan untuk menjadi responden secara sukarela. Prosedur pengolahan data terbagi atas dua tahap, yakni pembuatan sistem kategorisasi dan studi eksplorasi motivasi relawan. Kategorisasi dilakukan dengan menggunakan hasil temuan dari Clary dkk (1998); Omoto dan Snyder (1995); Allison, Okun, dan, Dutrige (2002); Chacón dan Vecina (1999); serta (Chacón dkk., 2010b) yang meneliti motivasi pada relawan. Dari proses tersebut, didapatkan 13 kategori motivasi relawan. Kemudian, dua kelompok juri, di mana setiap kelompoknya terdiri atas dua orang bersamasama mengklasifikasikan respon dari 50 peserta yang dipilih secara acak untuk menentukan kategori final berdasarkan jawaban yang muncul dari 50 subjek.
Setelah diperoleh kategori final, dua kelompok juri mengategorikan semua jawaban subjek secara independen sehingga diperoleh kategori motivasi masing-masing subjek. Hasil kategorisasi dari tiap kelompok kemudian dibandingkan. Jika ada perbedaan hasil kategorisasi, dilakukan kalibrasi yang difasilitasi oleh satu orang fasilitator. Hasil kalibrasi ini dijadikan acuan untuk menentukan hasil kategori final. Setelah semua subjek dikategorikan motivasinya, dilakukan analisis kuantitatif deskriptif untuk mendapatkan proporsi motivasi menjadi relawan. Analisis tambahan dilakukan untuk mencermati perbedaan motivasi relawan pada beberapa aspek demografi serta perbedaan intensi menjadi relawan ditinjau dari jenis motivasinya.

\section{Teknik analisis}

Data yang diperoleh dari jawaban responden dikategorikan sesuai dengan kemiripan dengan kategori yang ada pada penelitian terdahulu. Setelah didapatkan kategorisasi, kemudian dihitung frekuensi masing-masing kategori. Analisis selanjutnya dilakukan secara kuantatif deskriptif dengan bantuan program SPSS 23 (Statistic Package for Social Sciences). Proses 
berikutnya, untuk melihat adanya perbedaan motivasi relawan pada beberapa aspek demografi (jenis kelamin dan usia) dilakukan analisis tabulasi silang dengan menguji nilai chi-square. Sementara untuk melihat perbedaan intensi untuk menjadi relawan kembali berdasarkan jenis motivasi, dilakukan analisis One-way Anova.

\section{Hasil Penelitian}

\section{Kategori Motivasi Relawan}

Sebanyak 50 responden penelitian yang dipilih secara acak digunakan dalam perumusan kategori motivasi. Jawaban dari 50 responden tersebut dikategorisasikan oleh dua kelompok juri dengan mengacu pada 13 kategorisasi yang sudah ditemukan pada penelitian sebelumnya (Allison, Okun, \&, Dutrige, 2002; Chacón \& Vecina, 1999; Chacón dkk., 2010; Clary dkk, 1998; Omoto \& Snyder, 1995). Dari 13 kategori yang ada, ternyata hanya delapan kategori yang muncul dan relevan dengan jawaban responden penelitian. Delapan kategori motivasi relawan yang baru sebagai pemaknaan subjektif responden adalah sebagai berikut.

\section{Personal Value (Nilai Pribadi)}

Aspek ini mengacu pada nilai-nilai pribadi bersifat altruistik yang melandasi seseorang untuk melakukan perilaku menolong melalui kegiatan kerelawanan. Contoh jawaban yang menunjukkan nilai pribadi adalah "panggilan hati untuk bermanfaat bagi orang lain" dan "panggilan jiwa".

\section{Personal Development (Pengembangan Diri)} Motivasi untuk terlibat dalam kegiatan kerelawanan adalah adanya kesempatan untuk mengembangkan diri melalui pengalaman di lapangan. Lewat aktivitas kerelawanan, relawan mendapatkan tambahan ilmu dan keterampilan yang berguna untuk pengembangan kapasitas diri maupun peningkatan karirnya. Contoh jawaban yang menunjukkan pengembangan diri adalah "mengasah soft skill dan membangun jejaring" dan "menambah pengalaman".

3. Community Concern (Kepedulian Lingkungan) Motivasi untuk menolong muncul karena adanya kepedulian terhadap isu tertentu yang ada di masyarakat. Individu juga merasa dirinya memiliki sumber daya untuk berkontribusi menyelesaikan problem tersebut. Contoh jawaban yang menunjukkan kepedulian sosial adalah "ingin lingkungan lebih baik" dan "ketertarikan dengan kondisi pendidikan di daerah sasaran".
4. Interest in The Activity (Minat Kegiatan)

Motivasi untuk melakukan kegiatan kerelawanan karena aktivitasnya sesuai dengan minat pribadi, tidak terlalu memperhatikan tujuan dari organisasi atau komunitas relawan tempat bernaung. Contoh jawaban yang me-nunjukkan minat adalah "Menyukai dunia mengajar dan tertarik menjadi relawan tutor" dan "saya menyukai apa yang saya lakukan dalam kegiatan kerelawanan".

\section{Positive Feeling (Perasaan Positif)}

Ada perasaan-perasaan positif yang dirasakan karena telah melakukan perilaku menolong atau terlibat dalam kegiatan kerelawanan. misalnya kebanggaan, kebahagiaan, lega, merasa aktivitasnya menyenangkan atau menghibur, serta memperbaiki suasana hati yang buruk. Contoh jawaban yang menunjukkan perasaan positif adalah "karena menyenangkan" dan "ada kepuasan tersendiri ketika terlibat menjadi relawan".

\section{Protective (Protektif)}

Motivasi seseorang untuk terlibat dalam kegiatan kerelawanan dilihat sebagai cara mengurangi perasaan negatif akibat melihat permasalahan sosial atau penderitaan orang lain. Protektif dilihat responden sebagai sebuah mekanisme pertahanan ego (ego-defense mechanism) berupa eksternalisasi penderitaan diri sendiri dengan merasa setidaknya dirinya sendiri lebih beruntung daripada orang lain. Contoh jawaban yang menunjukkan protektif adalah "Ada rasa ingin berbagi ilmu bagi adikadik di pedalaman yang tidak mempunyai fasilitas yang berkecukupan" dan "karena ingin membantu sesama yang kurang beruntung".

7. Social Relation (Hubungan Sosial)

Motivasi untuk terlibat dalam kegiatan kerelawanan dilihat responden sebagai dorongan dari lingkungan sosial untuk melakukan kegiatan tersebut. Ada keinginan untuk terlibat atau masuk dalam golongan tertentu yang dianggapnya lebih baik karena telah melakukan perilaku menolong lewat kegiatan kerelawanan. Contoh jawaban yang menunjukkan hubungan sosial adalah "karena meniru kebiasaan orang tua" dan "bertemu teman sevisi".

\section{Religiosity (Religiositas)}

Motivasi untuk menolong muncul karena sebab-sebab religius, misalnya merasa hal tersebut sebagai perintah atau kewajiban dari Tuhan, ada perasaan bersyukur karena hidupnya berkelimpahan sehingga merasa perlu untuk menjadi saluran berkat bagi orang lain. Contoh jawaban yang menunjukkan religio- 
sitas adalah "ungkapan syukur pada Tuhan" dan "sarana muhasabah diri agar lebih bersyukur".

Delapan kategori tersebut kemudian menjadi dasar melakukan kategorisasi jawaban 315 responden yang ada. Satu responden bisa jadi memiliki lebih dari satu motivasi. Hasil kategorisasi seluruh responden dapat dilihat pada tabel 2. Dari hasil kategorisasi seluruh relawan, terlihat bahwa mayoritas memiliki motivasi nilai pribadi $(32,2 \%)$, sementara motivasi yang paling sedikit yaitu religiositas $(4,7 \%)$.

Tabel 2.

Kategori motivasi relawan

\begin{tabular}{lll}
\hline Motivasi & Frekuensi & Persentase \\
\hline Nilai Pribadi (NP) & 130 & $32,2 \%$ \\
Pengembangan Diri (PD) & 55 & $13,6 \%$ \\
Kepedulian Lingkungan (KL) & 51 & $12,6 \%$ \\
Minat Kegiatan (MK) & 47 & $11,6 \%$ \\
Perasaan Positif (PP) & 39 & $9,7 \%$ \\
Protektif (PR) & 35 & $8,7 \%$ \\
Hubungan Sosial (HS) & 28 & $6,9 \%$ \\
Religiositas (RL) & 19 & $4,7 \%$ \\
Total & 404 & $100 \%$ \\
\hline
\end{tabular}

Analisis selanjutnya adalah uji signifikansi statistik untuk melihat perbedaan motivasi berbasarkan jenis kelamin dan usia responden. Uji statistik dilakukan dengan tabulasi silang sehingga diperoleh nilai Chi-square. Hasil analisis tabulasi silang antara motivasi dan jenis kelamin menunjukkan nilai Pearson Chi-Square sebesar 6,751 dengan $p>0,05$. Dengan demikian dapat dinyatakan tidak ada asosiasi antara jenis kela- min dengan motivasi relawan. Sedangkan hasil analisis tabulasi silang antara motivasi dan usia menunjukkan nilai Pearson Chi-Square sebesar 24,73 dengan $\mathrm{p}<0,05$. Dengan demikian ada asosiasi yang signifikan antara usia dengan motivasi relawan. Data persentase motivasi relawan berdasarkan jenis kelamin dan usia dapat dilihat pada tabel 3 .

Tabel 3.

Persentase motivasi relawan berdasarkan jenis kelamin dan usia

\begin{tabular}{|c|c|c|c|c|c|c|c|c|c|c|}
\hline \multirow{2}{*}{\multicolumn{2}{|c|}{ Variabel demografi }} & \multicolumn{8}{|c|}{ Motivasi } & \multirow{2}{*}{ Total } \\
\hline & & NP & PD & HS & PR & KL & RL & PP & MK & \\
\hline \multirow{2}{*}{$\begin{array}{l}\text { Jenis } \\
\text { kelamin }\end{array}$} & Laki-Laki & $35,4 \%$ & $12,5 \%$ & $2,8 \%$ & $9 \%$ & $13,2 \%$ & $4,9 \%$ & $9,7 \%$ & $12,5 \%$ & $100 \%$ \\
\hline & Perempuan & $30,4 \%$ & $14,2 \%$ & $9,2 \%$ & $8,5 \%$ & $12,3 \%$ & $4,6 \%$ & $9,6 \%$ & $11,2 \%$ & $100 \%$ \\
\hline \multirow{3}{*}{ Usia } & 15-24 tahun & $32,4 \%$ & $13,0 \%$ & $4,6 \%$ & $13,9 \%$ & $12 \%$ & $5,6 \%$ & $7,4 \%$ & $11,1 \%$ & $100 \%$ \\
\hline & 25-34 tahun & $29,5 \%$ & $14,3 \%$ & $8,8 \%$ & $6 \%$ & $11,6 \%$ & $4,4 \%$ & $11,6 \%$ & $13,9 \%$ & $100 \%$ \\
\hline & $\begin{array}{l}35 \text { tahun ke } \\
\text { atas }\end{array}$ & $46,7 \%$ & $11,1 \%$ & $2,2 \%$ & $11,1 \%$ & $20 \%$ & $4,4 \%$ & $4,4 \%$ & $0 \%$ & $100 \%$ \\
\hline
\end{tabular}

Keterangan:

NP=Nilai Pribadi, PD=Pengembangan Diri, HS=Hubungan Sosial, PR=Protektif, KL=Kepedulian Lingkungan, RL=Religiusitas, $\mathrm{PP}=$ Perasaan Positif, MK=Minat Kegiatan

Analisis One-way Anova dilakukan untuk mengetahui perbedaan intensi untuk menjadi relawan kembali berdasarkan jenis motivasinya. Hasil analisis One-way Anova menunjukkan nilai $\mathrm{F}=2,04$ dan $\mathrm{p}<0,05$. Dengan demikian dapat disimpulkan bahwa ada perbedaan yang signifikan intensi untuk menjadi relawan kembali berdasarkan motivasinya. Rata-rata intensi menjadi relawan pada tiap kategori motivasi dapat dilihat pada Gambar 1. 
Gambar 1

Rata-rata intensi menjadi relawan berdasarkan motivasi

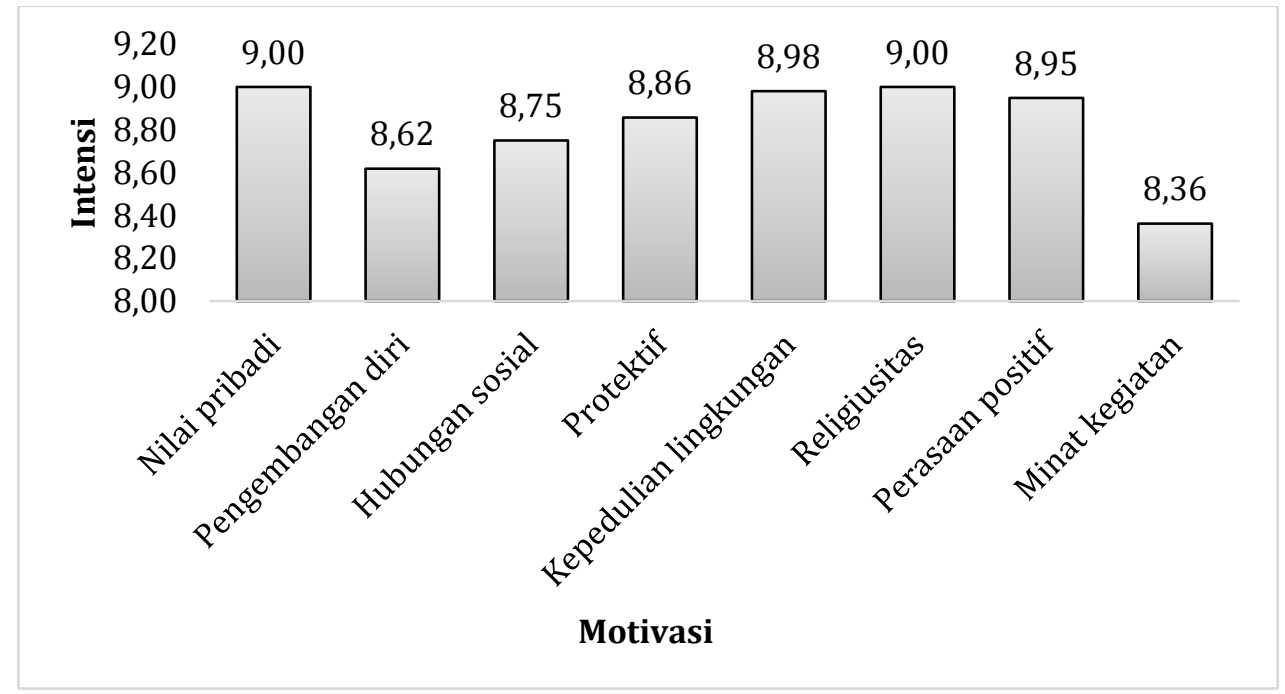

\section{Diskusi}

Penelitian ini bertujuan untuk mengeksplorasi motivasi relawan yang ada di Indonesia. Hasil penelitian menunjukkan bahwa tidak semua kategori pada penelitian terdahulu relevan dalam konteks masyarakat Indonesia. Data yang diperoleh peneliti menemukan bahwa dari 13 kategori motivasi relawan (Allison, Okun, \&, Dutrige, 2002; Chacón \& Vecina, 1999; Chacón dkk., 2010; Clary dkk, 1998; Omoto \& Snyder, 1995), terdapat delapan kategori yang dinilai relevan dan populer bagi relawan di Indonesia, yaitu Nilai Pribadi, Pengembangan Diri, Hubungan Sosial, Protektif, Kepedulian Lingkungan, Religiositas, Perasaan Positif, dan Minat Kegiatan.

Temuan ini penting untuk dijelaskan karena paradigma indigenous psychology yang digunakan dalam penelitian ini adalah indigenization from without di mana terdapat proses asimilasi serta indigenisasi konsep dari luar konteks budaya yang diteliti melalui proses adaptasi, penyesuaian, dan penerjemahan konsep sehingga menjadi lebih relevan dengan konteks budaya asli (Faturochman, Minza, \& Nurjaman, 2017). Hal inilah yang menjadi alasan 13 kategori dari penelitian terdahulu tidak dapat terakomodasi seluruhnya. Peneliti telah melakukan asimilasi berbagai kategori yang ada hingga membentuk delapan kategori baku yang dinilai telah sesuai dengan konteks masyarakat Indonesia.

Lebih lanjut, penelitian ini menunjukkan bahwa nilai pribadi dengan persentase sebesar $32,2 \%$ menjadi motif utama yang mendorong individu melakukan kegiatan kerelawanan. Hal ini sejalan dengan kajian teoritik sebelumnya bahwa volunteerism yang merupakan representasi dari perilaku prososial akan lebih banyak dilakukan berdasarkan nilai-nilai personal secara sukarela dengan sedikit melibatkan kepentingan yang menguntungkan secara individual (Baron \& Brascombe, 2012; Baron \& Byrne, 2004). Nilainilai yang dianut secara personal justru mengarah pada kebermanfaatan secara kolektif atau disebut dengan communal sharing dalam relasi sosial (Fiske, 1992). Alasan ini juga dapat dijadikan rujukan mengapa pada hasil penelitian masyarakat Indonesia melakukan aktivitas kerelawanan karena faktor kepedulian lingkungan. Sementara motivasi religiositas menjadi jenis motivasi yang paling sedikit digunakan oleh relawan. Dalam konteks ini, pemaknaan agama pada aspek ketuhanan dan ibadah-ibadah ritual (vertikal) lebih dominan dibandingkan pemaknaan secara horizontal seperti membantu sesama dan menjaga hak hidup sesama.

Temuan lain penelitian ini adalah terdapat perbedan motivasi menjadi relawan antara kelompok usia remaja akhir, dewasa dini, dan dewasa madya. Berdasarkan temuan di atas, subjek yang berada dalam kelompok usia remaja akhir (15-24 tahun) dan dewasa dini (24-34 tahun) mayoritas memiliki motivasi nilai pribadi dan pengembangan diri. Sesuai dengan tugas perkembangannya, melalui kegiatan kerelawanan individu mencapai peran sosial dan turut berkontribusi sebagai anggota masyarakat. Adapun motivasi untuk mengembangkan diri bisa dimaknai sebagai tahap eksplorasi dalam memilih jejak karir sebagai persiapan untuk membangun kondisi perekonomian diri sendiri yang lebih matang (Super, 1990). Sementara itu, 
individu berusia dewasa madya (lebih dari 35 tahun) pada umumnya sudah mulai mapan dengan kondisi perekonomiannya, tidak lagi melihat bahwa kegiatan kerelawanan sebagai jembatan untuk melakukan pengembangan diri. Oleh karena itu, mereka termotivasi melakukan kegiatan kerelawanan berdasarkan nilai pribadi yang dimilikinya dan kepedulian terhadap sesama.

Temuan tersebut hampir sama dengan temuan penelitian sebelumnya dari Dávila \& Díaz-Morales (2009) yang menemukan bahwa semakin meningkat usia, motivasi karir, pemahaman, dan mencari relasi semakin menurun. Sementara itu motivasi nilai pribadi relatif meningkat dari waktu ke waktu. Motivasi karir, pemahaman, dan mencari relasi erat kaitannya dengan kategori pengembangan diri dalam penelitian ini. Semakin bertambah usia seseorang, maka motivasi pada hal tersebut semakin menurun karena pada umumnya individu tersebut sudah tidak lagi memikirkan dirinya sendiri. Sementara itu, motivasi nilai pribadi hampir selalu berperan penting pada setiap kategori usia, tetapi peranannya semakin meningkat pada individu usia lanjut.

Penelitian ini juga menunjukkan hasil bahwa terdapat perbedaan intensi untuk menjadi relawan ditinjau dari motivasinya. Individu yang memiliki motivasi nilai pribadi dan religiositas memiliki intensi yang paling tinggi untuk kembali menjadi relawan. Hal ini selaras dengan temuan Lee, Alexander, \& Kim (2013) yang menemukan bahwa nilai pribadi merupakan prediktor paling besar yang menentukan intensi menjadi relawan. Selain itu munculnya motivasi religiositas sebagai prediktor yang kuat dalam menentukan intensi juga berkaitan dengan hasil penelitian Law \& Shek (2009) yang mengatakan bahwa kepercayaan (beliefs) dan tujuan hidup merupakan prediktor kuat intensi menjadi relawan. Hal ini berlaku untuk konteks masyarakat Indonesia karena tujuan hidup dan kepercayaan banyak dipengaruhi oleh keyakinan terhadap agama yang dianut.

Sementara itu, individu yang memiliki motivasi pengembangan diri dan minat kegiatan memiliki intensi menjadi relawan yang lebih rendah. Temuan ini bertentangan dengan temuan dari Wang (2004) yang mengatakan bahwa motivasi minat terhadap kegiatan dan potensi pengembangan diri merupakan faktor yang mendorong menjadi relawan. Hal ini berkaitan dengan jenis motivasi pengembangan diri yang sifatnya eksternal. Ryan dan Deci (2000) menyatakan suatu kegiatan yang didasarkan atas motivasi eksternal hanya akan berlangsung jika reward dari kegiatan tersebut terus diberikan. Dengan demikian, individu yang merasa reward yang diterima sudah tidak cukup maka akan cenderung tidak melanjutkan kegiatan. Selain itu perbedaan hasil ini sangat mungkin dipengaruhi oleh perbedaan bidang kerelawanan responden. Dalam penelitian Wang (2004) responden merupakan relawan pada bidang olah raga, sementara responden penelitian ini beragam dari berbagai bidang.

Penelitian ini menunjukkan bahwa motivasi nilai pribadi dan pengembangan diri merupakan motivasi yang paling paling sering muncul pada relawan. Implikasi dari temuan ini bagi organisasi yang membutuhkan tenaga relawan adalah dengan mengemas pesan rekrutmen yang menonjolkan keuntungan menjadi relawan baik itu secara personal maupun sosial. Selain itu, hasil penelitian ini menunjukkan bahwa pada usia 35 tahun ke atas, relawan cenderung termotivasi oleh nilai pribadi dan kepedulian lingkungan, sementara pada usia yang lebih muda relawan lebih termotivasi oleh dorongan untuk melakukan pengembangan diri. Maka, strategi rekrutmen bagi kelompok usia tertentu dapat lebih difokuskan dengan cara mengakomodasi motivasi calon relawan. Misalnya rekrutmen dengan sasaran relawan usia 35 tahun ke bawah lebih menonjolkan keuntungan pengembangan diri yang bisa didapatkan, sementara relawan usia 35 tahun ke atas lebih menonjolkan pesan yang menggugah kepedulian sosial. Hasil penelitian Peterson (2004) dapat dijadikan contoh dimana strategi rekrutmen yang paling baik dan membuat relawan bertahan adalah dengan fokus pada pemenuhan ideologi individu.

Implikasi lain berkaitan dengan temuan penelitian ini bagi pengelolaan relawan adalah pada saat pemberian pelatihan atau orientasi bagi relawan. Penelitian ini menunjukkan bahwa relawan yang memiliki motivasi nilai pribadi dan religiositas cenderung memiliki intensi untuk kembali menjadi relawan di masa mendatang. Oleh karena itu, pelatihan bagi relawan harus mampu menginternalisasi nilai-nilai kerelawanan, di samping menyertakan nilai-nilai religiositas di dalamnya. Hal ini didukung dengan kajian literatur yang dilakukan Einolf (2018) pada berbagai penelitian tentang pengelolaan relawan. Einolf (2018) menyatakan bahwa rekrutmen yang berpusat pada motivasi calon relawan serta orientasi dan pelatihan pada relawan dengan penekanan pada internalisasi nilai dapat membuat relawan bertahan lebih lama dan bekerja lebih baik.

Penelitian ini masih memiliki beberapa keterbatasan. Kategori yang digunakan dalam penelitian ini didasarkan pada hasil kategorisasi dari penelitian terdahulu yang berasal dari Barat, sehingga kategori yang dihasilkan pun kurang mampu menonjolkan sensitivitas nilai pada 
budaya Indonesia. Pengambilan dan analisis data memang menggunakan prinsip bottom up, tetapi tidak dalam proses indigenization from within yang memungkinkan pembentukan kategori motivasi relawan lebih orisinal dan peka secara kultural. Penggunaan open-ended questionnaire yang tidak dilanjutkan dengan in-depth interview dalam penelitian ini juga memiliki kelemahan karena kurang mampu menggali motivasi relawan secara mendalam. Penelitian ini juga mengukur intensi menjadi relawan kembali dengan skala single-item. Di beberapa kasus penggunaan single-item memang lebih efisien dan menghasilkan hasil yang konsisten dengan multi-items, tetapi pengukuran dengan menggunakan single-item memiliki kelemahan. Salah satu kelemahan single-item berkaitan dengan reliabilitas dan validitas prediktif hasil pengukuran (Diamantopoulos, Sarstedt, Fuchs, Wilczynski, \& Kaiser, 2012). Subjek dalam penelitian ini juga mayoritas berasal dari Jawa dan di bidang pendidikan, sehingga hasil penelitian ini kurang dapat mewakili secara keseluruhan kondisi relawan di Indonesia.

\section{Kesimpulan}

Penelitian ini menghasilkan delapan kategori motivasi relawan, yaitu nilai pribadi, pengembangan diri, kepedulian lingkungan, minat kegiatan, perasaan positif, protektif, hubungan sosial, dan religiositas. Tidak ada perbedaan motivasi antara laki-laki dan perempuan, tetapi jenis motivasi berkaitan dengan usia dan intensi menjadi relawan. Terdapat perbedaan motivasi berdasarkan kategori usia. Intensi untuk menjadi relawan kembali paling tinggi ditemukan pada subjek yang memiliki motivasi nilai pribadi dan religiositas.

\section{Saran}

Saran bagi organisasi nirlaba dalam melakukan rekrutmen dan pengelolaan relawan yaitu dengan menitikberatkan pada konten rekrutmen yang sesuai dengan motivasi relawan di rentang usia tertentu. Selain itu, konten pelatihan juga perlu lebih menginternalisasi nilai pribadi dan religiositas. Peneliti selanjutnya perlu melakukan in-depth interview dan menambah variasi subjek, baik itu dari sisi organisasi maupun domisilinya.

\section{Daftar Pustaka}

Allison, L. D., Okun, M. A., \& Dutridge, K. S. (2002). Assessing volunteer motives: a comparison of an open-ended probe and Likert rating scales. Journal of
Community \& Applied Social Psychology, 12(4), 243-255. https://doi.org/10.1002/casp.677

Aydinli, A., Bender, M., \& Chasiotis, A. (2013). Helping and volunteering across cultures: Determinants of prosocial behavior. Online Readings in Psychology and Culture, 5(3), 6.

Baron, R.A., Brascombe, N.R. (2012). Social psychology. United States of America: Pearson Education

Baron, R. A., Byrne, D. (2004). Psikologi sosial. Jakarta: Erlangga

Brunell, A. B., Tumblin, L., \& Buelow, M. T. (2014). Narcissism and the motivation to engage in volunteerism. Current Psychology, 33(3), 365-376. https://doi.org/10.1007/s12144-0149216-7

Burns, D. J., Reid, J., Toncar, M., Anderson, C., \& Wells, C. (2008). The Effect of Gender on the Motivation of Members of Generation Y College Students to Volunteer. Journal of Nonprofit \& Public Sector Marketing, 19(1), 99-118. https://doi.org/10.1300/J054v19n01_0 5

Butts, R. E. (1966). Feyerabend and the pragmatic theory of observation. Philosophy of Science, 33(4), 383-394. Diakses September 1, 2020, dari http://www.jstor.org/stable/186641

Carlo, G., Okun, M. A., Knight, G. P., \& de Guzman, M. R. T. (2005). The interplay of traits and motives on volunteering: Agreeableness, extraversion and prosocial value motivation. Personality and Individual Differences, 38(6), 1293-1305. https://doi.org/10.1016/j.paid.2004.08.0 12

Chacón, F., Pérez, T., Flores, J., \& Vecina, M. L. (2010). Motives for volunteering: categorization of volunteers'motivations using open-ended questions. intervención Psicosocial, 19(3), 213-222.

Clary, E. G., Snyder, M., Ridge, R. D., Copeland, J., Stukas, A. A., Haugen, J., \& Miene, P. (1998). Understanding and assessing the motivations of volunteers: a functional approach. Journal of personality and social psychology, 74(6), 1516.

Dávila, M. C., \& Díaz-Morales, J. F. (2009). Age and motives for volunteering: Further evidence. Europe's Journal of Psychology, $5(2)$, 82-95. https://doi.org/10.5964/ejop.v5i2.268

Diamantopoulos, A., Sarstedt, M., Fuchs, C., Wilczynski, P., \& Kaiser, S. (2012). Guidelines for choosing between multi- 
item and single-item scales for construct measurement: a predictive validity perspective. Journal of the Academy of Marketing Science, 40(3), 434-449.

Einolf, C. (2018). Evidence-based volunteer management: A review of the literature. Voluntary Sector Review, 9(2), 153-176. https://doi.org/10.1332/204080518X1 5299334470348

Faturohcman, Minza, W.M., Nurjaman, T.A. (2017). Memahami dan Mengembangkan Indigenous Psychology. Yogyakarta: Pustaka Pelajar

Fiske, A.P. (1992). The Four Elementary Forms of Sociality: Framework for a Unified Theory of Social Relations. American Psychological Association, 99(4), 689723.

Gallup. (2018). The 2018 World's Most Generous Countries Report. Retrieved from https://www.gallup.com/analytics/245 165/worlds-most-generous-countries2018.aspx

Gebauer, J. E., Riketta, M., Broemer, P., \& Maio, G. R. (2008). Pleasure and pressure based prosocial motivation: Divergent relations to subjective well-being. Journal of Research in Personality, 42(2), 399-420. https://doi.org/10.1016/j.jrp.2007.07.002

Grant, A. M. (2008). Does Intrinsic Motivation Fuel the Prosocial Fire? Motivational Synergy in Predicting Persistence, Performance, and Productivity. Journal of Applied Psychology, 93(1), 48-58. https://doi.org/10.1037/00219010.93.1.48

Harrison, D. A. (1995). Volunteer Motivation and Attendance Decisions: Competitive Theory Testing in Multiple Samples From a Homeless Shelter. Journal of Applied Psychology, 80(3), 371-385. https://doi.org/10.1037/00219010.80.3.371

Ibrahim, N. A., \& Brannen, D. E. (1997). Implications of Gender Differences on the Motivation to Volunteer in Hospitals. Journal of Social Service Research, 22(4), 1-18. https://doi.org/10.1300/J079v22n04_0 1

Konrath, S., Ho, M. H., \& Zarins, S. (2016). The strategic helper: Narcissism and prosocial motives and behaviors. Current Psychology, 35(2), 182-194. https://doi.org/10.1007/s12144-0169417-3

Law, B. M. F., \& Shek, D. T. L. (2009). Beliefs about Volunteerism, Volunteering
Intention, Volunteering Behavior, and Purpose in Life among Chinese Adolescents in Hong Kong. The Scientific World JOURNAL, 9, 855-865. https://doi.org/10.1100/tsw.2009.32

Lee, K.-H., Alexander, A. C., \& Kim, D.-Y. (2013). Motivational Factors Affecting Volunteer Intention in Local Events in the United States. Journal of Convention \& Event Tourism, 14(4), 271-292. https://doi.org/10.1080/15470148.201 3.816646

Okun, M. A., \& Schultz, A. (2003). Age and motives for volunteering: Testing hypotheses derived from socioemotional selectivity theory. Psychology and Aging, 18(2), 231-239. https://doi.org/10.1037/08827974.18.2.231

Omoto, A. M., \& Snyder, M. (1995). Sustained helping without obligation: motivation, longevity of service, and perceived attitude change among AIDS volunteers. Journal of personality and social psychology, 68(4), 671.

Peterson, D. K. (2004). Recruitment strategies for encouraging participation in corporate volunteer programs. Journal of Business Ethics, 49(4), 371-386.

Ryan, R. M., \& Deci, E. L. (2000). Intrinsic and extrinsic motivations: Classic definitions and new directions. Contemporary educational psychology, 25(1), 54-67.

Schroeder, H.W. (1998) The motivations and values of ecosystem restoration volunteers, paper presented at the Seventh International Symposium on Society and Resource Management, University of Missouri-Columbia, 27-31 May

Schroeder, D.A., Graziano, W.G. (2018). Prosocial behavior. Nelson, T.D. (Eds). Getting Grounded in Social Psychology: The Essential Literature of Beginning Researchers. New York: Routledge

Siswomihardjo, S.W. (2017). Identifikasi Motivasi Relawan pada Pemasaran Politik. Disertasi Universitas Gadjah Mada. Tidak Diterbitkan

Slattery, P., Finnegan, P., \& Vidgen, R. (2019). Creating compassion: how volunteering websites encourage prosocial behaviour. Information and Organization, 29(1), 5776.

Smith, D. H. (1981). Altruism, volunteers, and volunteerism. Journal of Voluntary Action Research, 10(1), 21-36. https://doi.org/10.1177/08997640810 1000105 
Stavrova, 0., \& Siegers, P. (2014). Religious Prosociality and Morality Across Cultures: How Social Enforcement of Religion Shapes the Effects of Personal Religiosity on Prosocial and Moral Attitudes and Behaviors. Personality and Social Psychology Bulletin, 40(3), 315333.

https://doi.org/10.1177/01461672135 10951
Super, D. E. (1990). A life span, life-space approach to career development. In D. Brown, \& L. Brooks (Eds.), Career choice and development (2nd ed.). San Francisco: Jossey-Bass

Wang, P.Z. (2004). Assessing motivations for sports volunteerism. Advances in Consumer Research. 31,420-25 